IOS Press

\title{
Application timing of nitric oxide ameliorates on deleterious effects of salinity on growth and fruit quality of strawberry cv. 'Selva'
}

\author{
Babak Jamali and Saeid Eshghi* \\ Department of Horticultural Science, College of Agriculture, Shiraz University, Shiraz, Iran
}

Submitted 26 January 2014; accepted 1 March 2014

\begin{abstract}
.
BACKGROUND: The exogenous application of nitric oxide (NO) has proved to protect plant against deleterious impact of salinity.

OBJECTIVE: The probable influence of application timing has been neglected in most studies. In order to evaluate the influence of application timing of NO on 'Selva' strawberry plants the following experiments were carried out.

METHOD: After establishment of 'Selva' daughter plants they were sprayed using 50 or $75 \mu \mathrm{M}$ NO solution (Sodium nitroprusside was used as NO donor), one week before, simultaneously and one week after start of an established $40 \mathrm{mM} \mathrm{NaCl}$ salinity stress.

RESULTS: Indicated that saline conditions had adverse influence on plants and that NO at both concentrations ameliorated these salinity effects as plants treated with 50 or $75 \mu \mathrm{M}$ of NO had larger shoot and root dry weight, higher number of inflorescences and quality parameters such as TSS in comparison to salinity stress exposed plants. Time of application was important, and plants treated with $\mathrm{NO}$ one week before beginning of salinity stress had highest ameliorative effect.
\end{abstract}

CONCLUSION: It seems that application of NO prior the stress increases the stress avoidance strategy of plants.

Keywords: Application timing, nitric oxide, salinity, sodium nitroprusside, stress, tolerance

\section{Introduction}

Salinity is one of adverse environmental factors limiting the productivity of crop plants because most of them are sensitive to salinity caused by high concentration of salts in the soil [1]. Salinity, especially at higher levels causes both hyper ionic and hyper osmotic. The outcome of these effects may cause membrane damage, nutrient imbalance, altered levels of growth regulators, enzymatic inhibition and metabolic dysfunction, including photosynthesis which ultimately leads to plant death [2,3]. In recent decades, exogenous protectants such as hormones (e.g. GA 3 , ABA, and SA) antioxidants (ascorbic acid, glutathione, tocopherol) and signaling molecules (nitric oxide, hydrogen peroxide) have been found effective in mitigating salt-induced damages in plant [4-6]. Nitric oxide (NO), has now gained significant place in plant science, mainly due to its properties; free radical, small size, no charge, short-lived, highly diffusible across biological membranes and multi functional roles in plant growth and development [7].

${ }^{*}$ Corresponding author: Saeid Eshghi, Department of Horticultural Science, College of Agriculture, Shiraz University, Shiraz, Iran. Tel./Fax: +98 711 2286133; E-mail: eshghi@ shirazu.ac.ir. 
NO synthesis within plant organs and cells occurs through enzymatic and non-enzymatic reactions [8] and increases under saline conditions. NO helps to maintain a high $\mathrm{K} / \mathrm{Na}$ ratio in the cytosol [7] through increased expression of plasma membrane and/or tonoplast $\mathrm{H}^{+}$-ATPase and $\mathrm{H}^{+}$-PPase under salinity [9]. The exogenous application of NO has been proved to protect plant against deleterious impact of salinity. The exogenous sodium nitroprusside (SNP), a NO donor, significantly alleviated the oxidative damage of salinity in seedlings of rice [10], lupin [11], cucumber [12] enhanced seedlings growth [13], and increased dry weight of maize and Kosteletzkya virginica seedlings [14, 15]. Li et al. [16] observed that $\mathrm{NO}$ could alleviate the damage of salt stress $(50 \mathrm{mM} \mathrm{NaCl})$ by decreased ion leakage and malondialdehyde (MDA) and $\mathrm{H}_{2} \mathrm{O}_{2}$ content. Additionally, the presence of the NO donor enhanced the activities of superoxide dismutase (SOD), ascorbic peroxidase (APX) and catalase (CAT). David et al. [17] reported that NO enhanced biochemical adaptation during the seedling growth of sunflower plants under salinity conditions. Exogenous NO supplementation as SNP has significant ameliorating effect against $\mathrm{NaCl}$ induced oxidative damage in Cicer arietinum leaves as observed by Sheokand et al. [18]. Corpas et al. [19] reported that under salt stress the osmotic stress-activated protein kinase (NtOSAK) is activated by NO and confer stress signals. Seed soaking in SNP solution increased the germination rate as well as coleoptile and radicle growth [20]. Application of $100 \mu$ M SNP solution on tomato 'Hufan2496' caused $31 \%$ increase in shoot dry weight of plants under $100 \mathrm{mM} \mathrm{NaCl} \mathrm{salinity}$ stress [21].

Straw berry growing and production is an ever increasing industry around the globe, but is one of the most sensitive species to saline conditions [22]. Previous studies indicate that accumulation of salts and increased level of soil salinity may lead to damages to strawberry plant and reduction of yield and quality parameters [23-25]. This can lead to increased economical damages and higher cost of strawberry production, on the other hand SNP a widely used NO-donor, not only has the potential of alleviating abiotic stresses such as salinity, as tolerance of strawberry to salinity can be manipulated and changed by application of NO, but also may improve the quality and shelf-life of strawberry [26, 27]. There are many studies, reporting beneficial influence of NO on plant growth under saline conditions, but in most of them the time aspect of application (prior, simultaneous or following initiation of stress) has not been studied. The goal of the present study was to evaluate the application timing of NO, on some strawberry plant- vegetative and -reproductive parameters and on quality characteristics of fruits under salinity.

\section{Materials and methods}

\subsection{Plant growth conditions and treatments}

Rooted uniform daughter plants of strawberry 'Selva' were potted in $3 \mathrm{~L}$ plastic pots filled with $1: 1$ ratio of peat moss and perlite. Plants were grown hydroponically under greenhouse conditions; they were fertigated with $150 \mathrm{~mL}$ of Hoagland solution once a day. Surpluses of solution were allowed to pass the containers to ensure salt stress in the root medium at given concentration, but to avoid anoxia by water logging. Average day and night temperatures were $21 \pm 2 / 17 \pm 2{ }^{\circ} \mathrm{C}$. Relative humidity was about $60 \pm 5 \%$. After establishment of plants treatments were foliar applied on plants. Treatments included:

1. Control plants grown under optimum conditions and sprayed with distilled water.

2. Plants grown under optimum conditions and sprayed with $50 \mu \mathrm{M} N O$ solution $\left(\mathrm{NO}_{50}\right)$.

3. Plants grown under optimum conditions and sprayed with $75 \mu \mathrm{M}$ NO solution $\left(\mathrm{NO}_{75}\right)$.

4. Plants exposed to $40 \mathrm{mM} \mathrm{NaCl}$ salinity and sprayed with distilled water.

5. Plants exposed to $40 \mathrm{mM} \mathrm{NaCl}$ salinity and sprayed with $50 \mu \mathrm{M}$ NO solution one week before start of salinity stress (Salinity $+\mathrm{NO}_{50}{ }^{-1}$ ).

6. Plants exposed to $40 \mathrm{mM} \mathrm{NaCl}$ salinity and sprayed with $75 \mu \mathrm{M}$ NO solution one week before start of salinity stress (Salinity $+\mathrm{NO}_{75}{ }^{-1}$ ).

7. Plants exposed to $40 \mathrm{mM} \mathrm{NaCl}$ salinity and sprayed with $50 \mu \mathrm{M} \mathrm{NO}$ solution simultaneously with start of salinity stress (Salinity $+\mathrm{NO}_{50}{ }^{0}$ ).

8. Plants exposed to $40 \mathrm{mM} \mathrm{NaCl}$ salinity and sprayed with $75 \mu \mathrm{M}$ NO solution simultaneously with start of salinity stress $\left(\right.$ Salinity $\left.+\mathrm{NO}_{75}{ }^{0}\right)$. 
9. Plants exposed to $40 \mathrm{Mm} \mathrm{NaCl}$ salinity and sprayed with $50 \mu \mathrm{M} \mathrm{NO}$ solution one week after start of salinity stress (Salinity $+\mathrm{NO}_{50}{ }^{+1}$ ).

10. Plants exposed to $40 \mathrm{Mm} \mathrm{NaCl}$ salinity and sprayed with $75 \mu \mathrm{M} \mathrm{NO}$ solution one week after start of salinity stress (Salinity $+\mathrm{NO}_{75}{ }^{+1}$ ).

For imposing salinity stress on plants $\mathrm{NaCl}$ salt at $40 \mathrm{mM}$ concentration was added to fertigation solution. Treatments were conducted in a completely randomized design with 4 replications.

\subsection{Measurements}

For measuring root and shoot dry weight (DW), the plants (4 pots in each treatment-categories and the rest were kept for measuring reproductive characteristics) were taken out of their pots four weeks after treatment start date and growth media was carefully washed off the shoot and root sections and the plant was then oven dried for 48 hours at $70^{\circ} \mathrm{C}$ and dry weight was determined and expressed as gram.

Leaf chlorophyll content was measured with a SPAD-502 chlorophyll-meter using 3 fully expanded leaves to find an average for chlorophyll content. Subsequently, 7 leaves (with their chlorophyll content already measured by SPAD-502) were randomly detached from the plants to extract chlorophyll by chemical method. Extraction was performed with $80 \%$ acetone and the yielded solution was centrifuged at $8000 \mathrm{rpm}$ for $10 \mathrm{~min}$. Chlorophyll content was determined using the following formula:

Chlorophyll $\left(\mathrm{mg} \mathrm{g}^{-1}\right.$ fresh weight $)=\left[20.2\left(\mathrm{~A}_{645}\right)+8.02\left(\mathrm{~A}_{663}\right) \times \mathrm{V}\right] /(1000 \mathrm{w})$ where $\mathrm{A}$ is absorption value, $\mathrm{V}$ is ultimate volume of extract and $\mathrm{W}$ is leaf fresh weight. A regression line and equation were obtained using Excel software, considering the SPAD-502 readings for the mentioned 7 leaves and colorimetrically determined chlorophyll contents. This equation was later used to estimate other chlorophyll readings from SPAD-502. Chlorophyll content was measured weekly (for four weeks) and an average was reported.

For leaf area, three fully expanded leaves of each plant, were chosen and total area was measured using a leaf area meter (Delta T Devices Ltd., Burwell, and Cambridge, England) and data were presented in $\mathrm{cm}^{2}$. This parameter was measured weekly (for four weeks) and an average was reported.

Number of inflorescences and flowers per inflorescence were counted for two months (from start date of treatments). Primary and secondary fruits were weighed using a digital scale and an average weight was calculated in gram. Length and diameter of fruits was measured by a digital caliper and expressed as $\mathrm{mm}$.

TSS (Total soluble solids) expressed in Brix ${ }^{\circ}$ was measured using a refractometer.

Total acid (\%) or TA\% (Titratable acid) was measured by the $\mathrm{NaOH}$ titration method: in $10 \mathrm{ml}$ of fruit juice, 5-6 droplets of phenolphthalein were added, then the mixture was titrated with $0.3 \mathrm{~N} \mathrm{NaOH}$ until a color change occurred. Then this formula was used:

$\% \mathrm{TA}=\left[\mathrm{ml}(\mathrm{NaOH}) \times \mathrm{N}(\mathrm{NaOH}) \times\right.$ acid. meq.factor ${ }^{+} \mathrm{ml}-1$ juice titrated $] \times 100$.

Ascorbic acid concentration in fruits was measured spectrophotometrically. To $100 \mu \mathrm{L}$ of fruit juice $10 \mathrm{ml}$ of methaphosphoric acid (1\%) was added, then to $1 \mathrm{ml}$ of this mixture $9 \mathrm{ml}$ of indophenol $(50 \mu \mathrm{M})$ was added and vortexed and read with spectrometer at $515 \mathrm{~nm}$. A calibration curve was prepared with known ascorbic acid concentrations. The results were expressed as $\mathrm{mg} / 100 \mathrm{~g}$ fresh weight.

The total polyphenols content was measured by the Folin-Ciocalteau reagent [28] using gallic acid as standard. The juice $(1 \mathrm{~mL})$ was mixed with $5 \mathrm{~mL}$ Folin-Ciocalteau reagent (previously diluted 10-fold with distilled water) and $4 \mathrm{~mL}$ sodium bicarbonate $(7.5 \% \mathrm{w} / \mathrm{v})$, and the mixture was diluted to $100 \mathrm{~mL}$ with distilled water. The solution was kept in the dark at room temperature for $2 \mathrm{~h}$; the absorbance was then measured at $765 \mathrm{~nm}$ with spectrophotometer. Total polyphenolics content was expressed as gallic acid equivalents (the concentration of gallic acid was established from a calibration curve) in $\mathrm{mg} / 100 \mathrm{~g}$ fresh weight (mg GAE/100 $\mathrm{g}$ fresh weight).

Total anthocyanins were measured spectrophotometrically using $\mathrm{pH}$ differential method with two buffer systems: potassium chloride buffer, $\mathrm{pH} 1.0(0.025 \mathrm{M})$ and sodium acetate buffer, $\mathrm{pH} 4.5(0.4 \mathrm{M})$ [29]. Briefly, $0.4 \mathrm{ml}$ of juice was mixed with $3.6 \mathrm{ml}$ of corresponding buffers and read against water as blank at 510 and $700 \mathrm{~nm}$. Absorbance (A) was calculated as

$$
A=(A 515-A 700) \mathrm{pH} 1.0-(A 510-A 700) \mathrm{pH} 4.5
$$


Then total anthocyanins content was calculated using the equation:

$$
\text { Anthocyanin }\left(\mathrm{mg} \cdot 100 \mathrm{~g} \text { fresh weight }{ }^{-1}\right)=(A \times \mathrm{MW} \times \mathrm{DF} \times 100) /(\varepsilon \times 1)
$$

Where $A$ is the absorbance of the diluted sample and DF is the dilution factor. MW and $\varepsilon$ in this formula correspond to the predominant anthocyanin in the sample. The pigment content was calculated as pelargonidin-3-glucoside, where $\mathrm{MW}=433.38$ and $\varepsilon=22.400$.

\subsection{Statistical analysis}

Data was analyzed by SPSS software and means were compared using Duncan's multiple range test.

\section{Results}

Table 1 indicates the effect of application time of NO $(50$ or $75 \mu \mathrm{M})$ and $40 \mathrm{mM}$ salinity on some vegetative parameters of strawberry 'Selva'. It shows that salinity caused reduction of shoot and root DW compared with control. Plants treated with NO (irrespective of NO level) one week before start of salinity stress, expressed no significant differences between these parameters similar to plants treated with NO alone or NO simultaneously with start of salinity stress; shoot and root DW decreased compared with control, $\mathrm{NO}_{50}$ and $\mathrm{NO}_{75}$ except for Salinity $+\mathrm{NO}_{50}{ }^{-1}$, but was higher than for plants exposed to salinity or salinity + No (irrespective of level) added one week after initiation of stress. NO treatments especially when applied prior to salinity stress start, reduced impact of salinity. In Salt stressed plants treated with $\mathrm{NO}_{50}$ one week after initiation of salt stress shoot and root DW were $79 \%$ and $71 \%$ of control in respect. Maximum of chlorophyll content was obtained from plants treated with $50 \mu \mathrm{M}$ NO solution alone, although there was no significant difference between these plants and samples of control, $\mathrm{NO}_{75}$ and salinity $+\mathrm{NO}_{50}{ }^{-1}$. $\mathrm{Plants}$ treated with NO (irrespective of NO level) one week after initiation of salt stress, had significantly lower chlorophyll content and there was no significant difference between salinity $+\mathrm{NO}_{75}{ }^{+1}$ and salt stressed plants without any NO treatments. Maximum of leaf area was obtained from plants treated with 75 and $50 \mu \mathrm{M}$ NO solutions alone and control. In plants treated with NO $(50$ or $75 \mu \mathrm{M})$ one week before or simultaneously with start of salinity stress, leaf area decreased compared to $\mathrm{NO}_{75}$ alone, but was higher than for plants exposed to saline conditions together with NO one week after initiation of salinity stress.

Table 2, indicates the effect of time of application of $\mathrm{NO}(50$ or $75 \mu \mathrm{M})$ and $40 \mathrm{mM} \mathrm{NaCl}$ salinity on some reproductive parameters of strawberry 'Selva'. All five parameters decreased following salinity stress compared to control. In plants treated with NO solution $(50$ or $75 \mu \mathrm{M})$, one week after initiation of saline conditions, number

Table 1

The effect of time of application of two levels of NO and $40 \mathrm{mM}$ salinity on some vegetative parameters of strawberry cv. 'Selva'

\begin{tabular}{|c|c|c|c|c|}
\hline Treatments & Shoot Dw (g) & Root Dw(g) & Leaf area $\left(\mathrm{cm}^{2}\right)$ & Chlorophyll content (mg.g $\left.{ }^{-1} \mathrm{FW}\right)$ \\
\hline Control & $12.6 \mathrm{a}^{\mathrm{z}}$ & $12.75 \mathrm{ab}$ & $31.75 \mathrm{ab}$ & $1.74 \mathrm{abc}$ \\
\hline Salinity & $6.82 \mathrm{~d}$ & $6.78 \mathrm{~d}$ & $27.25 \mathrm{~d}$ & $1.37 \mathrm{f}$ \\
\hline $\mathrm{NO}_{50}$ & $11.90 \mathrm{ab}$ & $13.61 \mathrm{a}$ & $31.66 \mathrm{ab}$ & $1.81 \mathrm{a}$ \\
\hline $\mathrm{NO}_{75}$ & $12.56 \mathrm{a}$ & $13.17 \mathrm{ab}$ & $32.00 \mathrm{a}$ & $1.72 \mathrm{abc}$ \\
\hline Salinity $+\mathrm{NO}_{50}{ }^{-1}$ & $11.88 \mathrm{ab}$ & $12.70 \mathrm{ab}$ & $30.81 \mathrm{bc}$ & $1.75 \mathrm{ab}$ \\
\hline Salinity $+\mathrm{NO}_{75}{ }^{-1}$ & $11.52 \mathrm{~b}$ & $12.22 \mathrm{ab}$ & $30.50 \mathrm{c}$ & $1.61 \mathrm{bcde}$ \\
\hline Salinity $+\mathrm{NO}_{50}{ }^{0}$ & $11.70 \mathrm{~b}$ & $12.00 \mathrm{~b}$ & $30.91 \mathrm{bc}$ & $1.63 \mathrm{bcd}$ \\
\hline Salinity $+\mathrm{NO}_{75}{ }^{0}$ & $11.33 \mathrm{~b}$ & $11.90 \mathrm{~b}$ & $30.50 \mathrm{c}$ & $1.60 \mathrm{cde}$ \\
\hline Salinity $+\mathrm{NO}_{50}+1$ & $10.07 \mathrm{c}$ & $9.11 \mathrm{c}$ & $27.60 \mathrm{~d}$ & $1.51 \mathrm{de}$ \\
\hline Salinity $+\mathrm{NO}_{75}+1$ & $10.15 \mathrm{c}$ & $9.78 \mathrm{c}$ & $27.75 \mathrm{~d}$ & $1.48 \mathrm{ef}$ \\
\hline
\end{tabular}

${ }^{\mathrm{z}}$ Means followed by the same letters within columns are not different at $5 \%$ probability using Duncan's multiple range test. $-1,0$ and +1 indicate the application timing ( -1 : one week before, 0 : simultaneously and +1 one week after start of salinity stress). 50 and 75 are NO concentrations $(\mu \mathrm{M})$. 
Table 2

The effect of time of application of two levels of NO and $40 \mathrm{mM}$ salinity on some reproductive parameters of strawberry cv. 'Selva'

\begin{tabular}{|c|c|c|c|c|c|}
\hline Treatments & Number of inflorescences & Flowers per inflorescences & Fruit weight (g) & Fruit length (mm) & Fruit diameter $(\mathrm{mm})$ \\
\hline Control & $3.07 \mathrm{a}^{\mathrm{z}}$ & $5.12 \mathrm{a}$ & $11.82 \mathrm{ab}$ & $34.43 \mathrm{ab}$ & $27.91 \mathrm{a}$ \\
\hline Salinity & $1.23 \mathrm{c}$ & $1.41 \mathrm{~d}$ & $9.55 \mathrm{c}$ & $29.12 \mathrm{~d}$ & $23.51 \mathrm{c}$ \\
\hline $\mathrm{NO}_{50}$ & $2.95 \mathrm{ab}$ & $4.44 \mathrm{~b}$ & $12.15 \mathrm{a}$ & $35.07 \mathrm{a}$ & $27.05 \mathrm{ab}$ \\
\hline $\mathrm{NO}_{75}$ & $2.72 \mathrm{ab}$ & $4.75 \mathrm{ab}$ & $12.12 \mathrm{a}$ & $35.15 \mathrm{a}$ & $26.70 \mathrm{~b}$ \\
\hline Salinity $+\mathrm{NO}_{50}{ }^{-1}$ & $2.81 \mathrm{ab}$ & $4.35 \mathrm{~b}$ & $11.58 \mathrm{ab}$ & $33.13 \mathrm{bc}$ & $26.40 \mathrm{~b}$ \\
\hline Salinity $+\mathrm{NO}_{75}{ }^{-1}$ & $2.51 \mathrm{~b}$ & $4.22 \mathrm{~b}$ & $11.33 \mathrm{ab}$ & $33.90 \mathrm{abc}$ & $27.00 \mathrm{ab}$ \\
\hline Salinity $+\mathrm{NO}_{50}{ }^{0}$ & $3.05 \mathrm{~b}$ & $4.41 \mathrm{~b}$ & $11.66 \mathrm{ab}$ & $33.41 \mathrm{abc}$ & $26.55 \mathrm{~b}$ \\
\hline Salinity $+\mathrm{NO}_{75}{ }^{0}$ & $3.11 \mathrm{a}$ & $4.31 \mathrm{~b}$ & $11.22 \mathrm{~b}$ & $33.85 \mathrm{abc}$ & $26.90 \mathrm{ab}$ \\
\hline Salinity $+\mathrm{NO}_{50}+1$ & $1.72 \mathrm{c}$ & $3.31 \mathrm{c}$ & $11.07 \mathrm{~b}$ & $33.12 \mathrm{bc}$ & $24.72 \mathrm{~b}$ \\
\hline Salinity $+\mathrm{NO}_{75}+1$ & $1.58 \mathrm{c}$ & $3.31 \mathrm{c}$ & $11.25 \mathrm{~b}$ & $32.51 \mathrm{c}$ & $26.45 \mathrm{~b}$ \\
\hline
\end{tabular}

${ }^{\mathrm{z}}$ Means followed by the same letters within columns are not different at $5 \%$ probability using Duncan's multiple range test. $-1,0$ and +1 indicate the application timing $(-1$ : one week before, 0 : simultaneously and +1 one week after start of salinity stress). 50 and 75 are NO concentrations $(\mu \mathrm{M})$.

Table 3

The effect of time of application of two levels of NO and $40 \mathrm{mM}$ salinity on some quality parameters of Selva strawberry fruits

\begin{tabular}{|c|c|c|c|c|c|}
\hline Treatments & $\begin{array}{c}\text { Vitamin C } \\
(\mathrm{mg} / 100 \mathrm{~g} \mathrm{FW})\end{array}$ & $\begin{array}{c}\text { Total acids } \\
(\%)\end{array}$ & $\begin{array}{l}\text { Anthocyanins } \\
(\mathrm{mg} / 100 \mathrm{~g} \mathrm{FW})\end{array}$ & $\begin{array}{l}\text { Total polyphenols } \\
(\mathrm{mg} / 100 \mathrm{~g} \mathrm{FW})\end{array}$ & $\begin{array}{l}\text { TSS } \\
(\%)\end{array}$ \\
\hline Control & $75.84 \mathrm{bc}^{\mathrm{z}}$ & $0.35 \mathrm{~g}$ & $31.54 \mathrm{~g}$ & $170.25 \mathrm{f}$ & $7.8 \mathrm{a}$ \\
\hline Salinity & $55.97 \mathrm{~g}$ & $0.82 \mathrm{a}$ & $30.08 \mathrm{~g}$ & $178.91 \mathrm{e}$ & $6.2 \mathrm{~b}$ \\
\hline $\mathrm{NO}_{50}$ & $71.57 \mathrm{de}$ & $0.40 \mathrm{fg}$ & $47.50 \mathrm{bc}$ & $215.19 \mathrm{bc}$ & $7.8 \mathrm{a}$ \\
\hline $\mathrm{NO}_{75}$ & 70.07 def & 0.45 ef & $44.93 \mathrm{de}$ & $210.38 \mathrm{~cd}$ & $7.7 \mathrm{a}$ \\
\hline Salinity $+\mathrm{NO}_{50}{ }^{-1}$ & 68.12 ef & $0.51 \mathrm{de}$ & $48.19 \mathrm{ab}$ & $229.12 \mathrm{a}$ & $7.6 \mathrm{a}$ \\
\hline Salinity $+\mathrm{NO}_{75}{ }^{-1}$ & $67.21 \mathrm{f}$ & $0.55 \mathrm{~cd}$ & $48.84 \mathrm{ab}$ & $222.07 \mathrm{ab}$ & $7.5 \mathrm{a}$ \\
\hline Salinity $+\mathrm{NO}_{50}{ }^{0}$ & $79.04 \mathrm{ab}$ & $0.53 \mathrm{~d}$ & $49.24 \mathrm{a}$ & $215.41 \mathrm{bc}$ & $7.7 \mathrm{a}$ \\
\hline Salinity $+\mathrm{NO}_{75}{ }^{0}$ & $81.81 \mathrm{a}$ & $0.55 \mathrm{~cd}$ & $46.40 \mathrm{~cd}$ & $211.09 \mathrm{~cd}$ & $7.8 \mathrm{a}$ \\
\hline Salinity $+\mathrm{NO}_{50}+1$ & $73.00 \mathrm{~cd}$ & $0.60 \mathrm{bc}$ & 43.86 ef & $209.88 \mathrm{~cd}$ & $7.6 \mathrm{a}$ \\
\hline Salinity $+\mathrm{NO}_{75}+1$ & $70.21 \mathrm{def}$ & $0.62 \mathrm{~b}$ & $40.63 \mathrm{f}$ & $205.11 \mathrm{~d}$ & $7.2 \mathrm{a}$ \\
\hline
\end{tabular}

${ }^{\mathrm{z}}$ Means followed by the same letters within columns are not different at $5 \%$ probability using Duncan's multiple range test. $-1,0$ and +1 indicate the application timing $(-1$ : one week before, 0 : simultaneously and +1 one week after start of salinity stress). 50 and 75 are NO concentrations $(\mu \mathrm{M})$.

of inflorescences and flowers per inflorescences decreased significantly in comparison to control. However, NO applications at both concentrations one week before or at initiation of salinity stress mitigated this reduction and in plants treated with $50 \mu \mathrm{M}$ NO solution one week before or 50 or $75 \mu \mathrm{M}$ NO solution simultaneously with start of salinity stress, number of inflorescences did not change significantly when compared with control samples. Results obtained for fruit weight were similar, while fruit-length and -diameter showed generally no or small differences after treatments but performed better than salinity. Salinity caused about $14 \%$ and $12 \%$ decrease in respectively fruit-length and-diameter compared to control; NO application at all times and both concentrations, alleviated these reductions; and fruits from plants treated with $75 \mu \mathrm{M}$ NO solution one week before or simultaneously with initiation of stress was not significantly different from control samples.

Table 3 indicates the time effect of NO application on plants suffering from salinity stress on some quality parameters of 'Selva' strawberry fruits. Ascorbic acid concentration (vitamin C), decreased significantly in plants exposed to saline stress, but reached its highest amount when plants were treated with $75 \mu \mathrm{M}$ NO simultaneously with start of salinity stress, though not different from $50 \mu \mathrm{M}$ NO used the same time. Fruits of those, treated with 
$75 \mu \mathrm{M}$ NO solution one week after beginning of salinity stress, had significantly lower vitamin C concentration in comparison to samples of control. Salinity stress caused increase in total acids (\%) of fruits, but NO applications of both concentrations and all application times reduced this increment. Total anthocyanins and polyphenolic compounds increased significantly following all NO applications, and the highest content of these two parameters were obtained from plants treated with $\mathrm{NO}_{50} \mu \mathrm{M}$ and $\mathrm{NO}_{75} \mu \mathrm{M}$ for respectively total polyphenol and total anthocyanins, added one week before initiation of salinity stress. Salinity decreased fruits TSS and NO application led to avoidance of this reduction.

\section{Discussion}

Vegetative parameters decreased significantly after exposure of plants to salinity stress. Decrease in biomass production is probably due to the observed cholorosis and necrosis of leaves that obviously reduced the photosynthetically active area which has been reported previously [30]. A vast range of studies reported reduction of shoot and/or root fresh and dry weight after exposure of plants to saline conditions [31-33]. There is a direct correlation between chlorophyll content of leaves and general plant health [34]. Total chlorophyll content may decrease under $\mathrm{NaCl}$ salinity stress in different species [35], and salinity stress causes changes in chloroplast ultrastructure [34]. Change of glutamate conversion to proline instead to chlorophyll might occur under such conditions, because of a shift in plant priorities towards better survival [36]. Application of NO in our experiments decreased these deleterious effects of salinity in accordance with previous studies in rice and maize seedlings [10, 14].

The results show that time of application was important, demonstrated by vegetative characteristics that decreased under saline conditions in comparison to control samples and earlier NO applications, in plants treated one week after exposure to salinity; however, performing better than plants grown under saline conditions. The reason might be adverse impact of salinity on plants which became permanent (conversion of elastic injuries to plastic) in those plants. As mentioned above there are several reports indicating beneficial and improving influence of NO on plant growth under stress conditions such as salinity. The mechanism cited for this effect is generally augmentation of antioxidant defense in plants treated with NO. In bitter orange (Citrus aurantium L.) trees, root pre-treatment with NO increased the activity of SOD, CAT, APX and glutathione reductase (GR), promoted maintenance of cellular redox homeostasis and mitigated oxidative damage under salt stress [37]. Exogenous application of NO protected chickpea (Cicer arietinum L.) plants from salinity-induced oxidative damage through increased activity of antioxidant enzymes including SOD, CAT, APX, GR and dehydro-ascorbate reductase and higher ratios of glutathione/glutathione disulfide and ascorbate/dehydroascorbate [38]. NO can also act as an antioxidant to protect plants from oxidative damage [39]. Moreover NO application has found to increase proline accumulation in wheat, that scavenges reactive oxygen species (ROS) and stabilize the structure of the macromolecules [40]. So NO gives the plants protection against oxidative damages induced by salinity if the adverse effect starts with a delay or at least simultaneously with NO application; in other words NO can "vaccinate" plants against adverse abiotic stress conditions [7]. Application of NO, after initiation of stress may also help the plant, but because the stress already has harmed the plants, the application may help to maintain the current conditions, inhibit worsening and even induce some recovery.

Salinity caused decrease in reproductive characteristics including fruit weight in our study. This effect on fruits is discussed by others; Awang and Atherton [41] reported in accordance with our results a decrease in strawberry fruit weight following salinity stress, on the other hand Saied et al. [25] reported a decrease in strawberry fruit numbers under saline conditions while fruit size was not significantly affected by stress. Sakamoto et al. [42] and Sato [43] proposed that salinity impair fruit weight by decreasing plant water potential. According to Keutgen and Pawelzik [44] a significant increase of $\mathrm{Na}^{+}$and $\mathrm{Cl}^{-}$in fruit impaired fruit weight and decrease in plant water potential and increase of $\mathrm{Na}^{+}$and $\mathrm{Cl}^{-}$can be retarded by NO application [7]. Flowering is energy consuming, and when plants were exposed to salinity and chlorophyll content and leaf area decreased, this could lead to reduced photosynthesis and assimilation, which in turn could lead to poorer development of inflorescences and/or flowers. Also, flowering and growth and ripening of fruits require a hormonal-nutritional balance, which is impaired under saline conditions [45]. That can be another reason responsible for reduction of fruit weight, size and number. NO has the ability to inhibit or at least reduce these impairment of hormonal-nutritional balance. Also time play an important role, if the essential signal (NO) reach the plant cells and organs in time, they can prepare themselves for dealing with detrimental 
effect of salinity, by higher activity of antioxidant defense system, osmoprotectants and increase in $\mathrm{K}^{+}$absorption. NO application after exposure to salinity might have beneficial influence, but because damage of excess salt already had been done to plants cells or organs, it did not increase plant health and/or growth (vegetative and reproductive) considerably in our experiments.

Total acids increased strongly by salinity but was modified by NO to levels between salinity and control in accordance with previous studies of Keutgen and Pawelzik [46], who found higher acetic and citric acid in strawberry fruits grown under saline conditions. Total growth and photosynthetic activity are affected under saline conditions, so it would be expected that fruits under such conditions may not reach an ideal level of each quality parameter. NO application had mitigating influence on salinity effects on plants and initiated a rise in their tolerance threshold. Moderate salinity may increase total fruit quality, which has been demonstrated in horticultural crops like tomato [47], cucumber [48] and sweet pepper [49]. Similar studies have been done on strawberry, and moderate salinity concentrations have been shown to increase antioxidant capacity in less sensitive strawberry cultivars [46]. Khayat et al. [50] could improve strawberry TSS and ascorbic acid concentration with moderate salinity and supplementary calcium. NO application without combination with salinity increased antioxidant compounds like total anthocyanins and polyphenol in our research, which are in accordance with experiments on other plant species indicating increment of plant enzymatic and non-enzymatic antioxidant system under adverse abiotic stress conditions [51-54]. NO, is an important bioactive signaling molecule that is involved in regulation of plant responses under stress conditions [13], and under salinity conditions synthesis of this molecule increases [8]. Application of NO mimicked stress conditions, and caused increase of antioxidants.

\section{Conclusions}

Salinity had adverse effect on both vegetative and reproductive growth of strawberry. This stress impairs quality parameters of strawberry fruits, but application of NO in proper time may mitigate these adverse impacts and improve quality of fruits. Point is that application of NO with delay compared to time of stress initiation may cause some injuries that become plastic, irreversible and permanent, and plant would require some time to recover. It seems that application of NO prior to the stress factor produces an avoidance strategy of plant stress or increases it. Applied later and especially after exposure of plants to stress conditions, it can be helpful and increase plant tolerance; however late application may introduce some elastic damages which may convert to plastic injuries.

\section{References}

[1] Hasanuzzaman M, Nahar K, Fujita M. Plant response to salt stress and role of exogenous protectants to mitigate salt-induced damages. In: Ahmad P, Azooz PP, Prasad MNV, editors. Ecophysilogy and responses of plants under salt stress. Berlin: Springer Verlag. 2013; pp. $25-87$.

[2] Mahajan S, Tateja N. Cold, salinity and drought stresses: An overview. Arch Biochem Biophysics. 2005;444:139-58.

[3] Hasanuzzaman M, Hossain MA, da-Silva JAT, Fujita M. 2012. Plant responses and tolerance to abiotic oxidative stress: Antioxidant defenses is a key factors. In: Bandi V, Shanker AK, Shanker C, Mandapaka M, editors. Crop stress and its management. Berlin: Springer Verlag. 2012; pp. 261-316.

[4] Nounjan N, Nghia PT, Theerakulpisut P. Exogenous proline and trehalose promote recovery of rice seedlings from salt-stress and differentially modulate antioxidant enzymes and expression of related genes. Plant Physiol. 2012;169:596-604.

[5] Iqbal N, Masood A, Khan NA. Phytohormones in salinity tolerance: Ethylene and gibberellins cross talk. In: Khan NA, Nazar R, Iqbal N, Anjum NA editors. Phytohormones and abiotic stress tolerance in plants. Berlin: Springer Verlag. 2012; pp. 77-98.

[6] Azzedine F, Gherroucha H, Baka M. Improvement of salt tolerance in durum wheat by ascorbic acid application. J Stress Physiol Biochem. 2011;7:27-37.

[7] Siddiqui MH, Al-Whaibi MH, Basala MO. Role of nitric oxide in tolerance of plants to abiotic stress. Protoplasma. 2011;248:447-55.

[8] Bethke PC, Gubler F, Jacobsen JV, Jones RL. Dormancy of Arabidopsis seeds and barley grains can be broken by nitric oxide. Planta. 2004;219:847-55.

[9] Shi Q, Ding F, Wang X, Wei M. Exogenous nitric oxide protect cucumber roots against oxidative stress induced by salt stress. Plant Physiol Biochem. 2007;45:542-50. 
[10] Uchida A, Jagendorf AT, Hibino T, Takabe T, Takabe T. Effects of hydrogen peroxide and nitric oxide on both salt and heat stress tolerance in rice. Plant Sci. 2002;163:515-23.

[11] Kopyra M, Gwóźdź EA. Nitric oxide stimulates seed germination and counteracts the inhibitory effect of heavy metals and salinity on root growth of Lupinus luteus. Plant Physiol Biochem. 2003;41:1011-17.

[12] Fan H, Guo S, Jiao Y, Zhang R, Li J. Effects of exogenous nitric oxide on growth, active oxygen species metabolism, and photosynthetic characteristics in cucumber seedlings under $\mathrm{NaCl}$ stress. Front Agric China. 2007;1:308-14.

[13] Song J, Shi G, Xing S, Chen M, Wang B. Effects of nitric oxide and nitrogen on seedling emergence, ion accumulation, and seedling growth under salinity in the euhalophyte Suaeda salsa. J Plant Nutr Soil Sci. 2009;172:544-9.

[14] Zhang YY, Wang LL, Liu YL, Zhang Q, Wei QP, Zhang WH. Nitric oxide enhances salt tolerance in maize seedlings through increasing activities of proton-pump and $\mathrm{Na}^{+} / \mathrm{H}^{+}$antiport in the tonoplast. Planta. 2006;224:545-55.

[15] Guo Y, Tian Z, Yan D, Zhang J, Qin P. Effects of nitric oxide on salt stress tolerance in Kosteletzkya virginica. Life Sci J. 2009;6:67-75.

[16] Li QY, Niud HB, Yind J, Wanga MB, Shao HB, Deng DZ, Chen XX, Ren JP, Li YC. Protective role of exogenous nitric oxide against oxidative-stress induced by salt stress in barley (Hordeum vulgare). Colloids and Surfaces B: Biointerfaces. 2008;65:220-5.

[17] David A, Yadav S, Bhatla SC. Sodium chloride stress induces nitric oxide accumulation in root tips and oil body surface accompanying slower oleosin degradation in sun flower seedlings. Physiol Plant. 2010;140:342-54.

[18] Sheokand S, Bhankar V, Sawhney V. Ameliorative effect of exogenous nitric oxide on oxidative metabolism in NaCl treated chickpea plants. Braz J Plant Physiol. 2010;22:81-90.

[19] Corpas FJ, Leterrier M, Valderrama R, Airaki M, Chaki M, Palma JM, Barroso JB. Nitric oxide imbalance provokes a nitrosative response in plants under abiotic stress. Plant Sci. 2011;181:604-11.

[20] Zheng C, Jiang D, Liu F, Dai T, Liu W, Jing Q, Cao W. Exogenous nitric oxide improves seed germination in wheat against mitochondrial oxidative damage induced by high salinity. Environ Exp Bot. 2009;67:222-7.

[21] Wu X, Zhu W, Zhang H, Ding H, Zhang HJ. Exogenous nitric oxide protects against saltinduced oxidative stress in the leaves from two genotypes of tomato (Lycopersicom esculentum Mill.). Acta Physiol Plant. 2001;33:1199-209.

[22] Yilmaz H, Kina A. The influence of $\mathrm{NaCl}$ salinity on some vegetative and chemical changes of strawberries (Fragaria $\times$ ananassa L.). Afric J Biotech. 2008;7(18):3299-305.

[23] Kepenek K, Koyuncu F. Studies on the salt tolerance of some strawberry cultivars under glasshouse. Acta Hort. 2002;57:297-305.

[24] Keutgen AJ, Keutgen N. Influence of NaCl salinity stress on fruit quality in strawberry. Acta Hort. 2003;609:155-7.

[25] Saied AS, Keutgen AJ, Noga G. The influence of $\mathrm{NaCl}$ salinity on growth, yield and fruit quality of strawberry cultivars 'Elsanta' and 'Korona'. Sci Hort. 2005;103:289-303.

[26] Zhu S, Zhou J. Effect of NO on ethylene production in strawberry fruit during storage. Food Chem. 2007;100:1517-22.

[27] Abdollahi R, Asghari M, Esmaili M, Abdolalhi A. Postharvest nitric oxide treatment effectively reduced decays of selva strawberry fruit. Int J Agric Crop Sci. 2013;6(6):353-5.

[28] Aaby K, Eckeberg E, Skered G. Characterization of phenolic compounds in strawberry (Fragaria $\times$ ananassa Duch.) fruits by different HPLC detectors and contribution of individual compounds to total antioxidant capacity. J Agric Food Chem. 2007;55(11):4395-405.

[29] Lako J, Trenerry VC, Rochfort S. Routine analytical methods for use in South Pacific regional laboratories for determining naturally occurring antioxidants in food. Int Food Res J. 2007;15(3):313-23.

[30] De-Herralde F, Biel C, Savé R, Morales MA, Torrecillas A, Alarcó JJ, Sánchez- Blanco MJ. Effect of water and salt stresses on the growth, gas exchange and water relations in Argyranthemum coronopifolium plants. Plant Sci. 1992;139:9-17.

[31] Khan NA, Nazar R, Anjum NA. Growth, photosynthesis and antioxidant metabolism in mustard (Brassica juncea L.) cultivars differing in ATP-sulphurylase activity under salinity stress. Sci Hort. 2009;122:455-60.

[32] Shannon MC, Grieve CM, Francoise LE. Whole-plant response to salinity. In: Wilkinson RE editor. Plant environment interactions. New York: Dekker. 1994; pp. 199-244.

[33] Jaleel CA, Manivannan P, Lakshmanan GMA, Sridharan R, Panneerselvam R. NaCl as a physiological modulator of proline metabolism and antioxidant potential in Phyllanthus amarus. Comptes Rendus Biologies. 2007;330:806-13.

[34] Mane AV, Deshpande TV, Wagh WB, Karadge BA, Samant JS. A critical review on physiologlical changes associated with reference to salinity. Int J Environ Sci. 2011;6:1192-216.

[35] Kaya C, Akb E, Higgs D. Response of salt-stressed strawberry plants to supplementary calcium nitrate and/or potassium nitrate. J Plant Nutr. 2003;26:543-60

[36] Madhava RKV, Raghavendra AS, Janardhan RK. Physiology and molecular biology of stress tolerance in plant. Netherlands Springer. 2006; p. 345.

[37] Tanou G, Molassiotis A, Diamantidis GR. Hydrogen peroxide- and nitric oxide-induced systemic antioxidant prime-like activity under $\mathrm{NaCl}$-stress and stress free conditions in citrus plants. J Plant Physiol. 2009;166:1904-13.

[38] Sheokand S, Bhankar V, Sawhney V. Ameliorative effect of exogenous nitric oxide on oxidative metabolism in NaCl treated chickpea plants. Braz J Plant Physiol. 2010;22:81-90.

[39] Beligni MV, Fath A, Bethke PC, Lamattina L, Jones RL. Nitric oxide acts as an antioxidant and delays programmed cell death in barley aleurone layers. J Plant Physiol. 2002;129:1642-50. 
[40] Ruan H-H, Shen W, Ye M, Xu L. Protective effects of nitric oxide on salt-induced damages oxidative damages to wheat (Triticum aestivum) leaves. Chinese Sci Bull. 2002;47:677-81.

[41] Awang YB, Atherton JG. Salinity and shading effects on leaf water relations and ionic composition of strawberry plants grown on rockwool. J Hort Sci. 1994;69:377-83.

[42] Sakamoto Y, Watanabe S, Nakashima T, Okano K. Effects of salinity at two ripening stages on the fruit quality of single-truss tomato grown in hydroponics. J Hort Sci Biotech. 1999;74:690-3.

[43] Sato S, Sakaguchi S, Furukawa H, Ikeda $\mathrm{H}$. Effects of $\mathrm{NaCl}$ application to hydroponic nutrient solution on fruit characteristic of tomato (Lycopersicon esculentum Mill.). Sci Hort. 2006;109:248-53.

[44] Keutgen AJ, Pawelzik E. Contribution of amino acids to strawberry fruit quality and their relevance as stress indicators under NaCl salinity. J Agric Food Chem. 2008;111:642-7.

[45] Taiz L, Zeiger E. Plant Physiology. Sinauer Associates Inc. 2010; p. 782.

[46] Keutgen AJ, Pawelzik E. Modifications of taste-relevant compounds in strawberry fruit under NaCl salinity. Food Chem. 2007;105(4): 1487-94.

[47] Adams P. Effects of increasing the salinity of the nutrient solution with major nutrients or sodium chloride on the yield, quality and composition of tomatoes grown in rockwool. J Hort Sci. 1991;66:201-7.

[48] Janse J. Effects of humidity, temperature and concentration of the nutrient solution on firmness, shelflife and flavor of sweet pepper fruits (Capsicum annum L.). Acta Hort. 1989;244:123-32.

[49] Chartzoulakis KS. Effects of NaCl salinity on germination, growth and yield of greenhouse cucumber. J Hort Sci. 1992;67:115-19.

[50] Khayat M, Tafazoli E, Eshghi S, Rahemi M, Rajaee S. Salinity, Supplementary Calcium and Potassium Effects on Fruit Yield and Quality of Strawberry (Fragaria ananassa Duch.). Am Eurasian J Agric Environ Sci. 2007;2(5):539-44.

[51] Mahmoudi H, Huang J, Gruber MY, Kaddour R, Lachaal M, Ouerghi Z, Hannoufa A. The impact of genotype and salinity on physiological function, secondary metabolite accumulation, and antioxidative responses in lettuce. J Agric Food Chem. 2010;58:5122-30.

[52] Yuan G, Wang X, Guo R, Wang Q. Effect of salt stress on phenolic compounds, glucosinolates, myrosinase and antioxidant activity in radish sprouts. Food Chem. 2010;121:1014-9.

[53] Petridis A, Therios I, Samouris G, Tananaki C. Salinity-induced changes in phenolic compounds in leaves and roots of four olive cultivars (Olea europaea L.) and their relationship to antioxidant activity. Environ Exp Bot. 2012;79:37-43.

[54] Dkhil BB, Denden M. Salt stress induced changes in germination, sugars, starch and enzyme of carbohydrate metabolism in Abelmoschus esculentus L. (Moench.) seeds. Afric J Agric Res. 2010;5:1412-8. 